\title{
Why I . . launched a lunch club for trainees
}

\section{Anaesthetic trainee Mat Devlin tells Francesca Robinson why he and a colleague created a space where trainees could share a meal, socialise, and learn together}

\section{Francesca Robinson freelance journalist}

Hampshire, UK

Keen to do something to tackle the risk of burnout and isolation among their peers, Mat Devlin and Rachel Cassin, anaesthetic core trainees based at Manchester NHS Foundation Trust, decided to build camaraderie and improve teamwork by setting up a weekly lunch club.

The initial launch of the club-for a cohort of anaesthetic trainees-was successful and attracted up to 10 people at a time. The hour long meetings combined informal education and a chance to socialise. The club gave attendees the opportunity to discuss their day and share experiences, but Devlin says he didn't allow gripes about work.

The club, Devlin says, also gave those new to anaesthetics the chance to get feedback from more experienced trainees who were often able to reassure them that how they were feeling was appropriate for that stage of their career. "It was a safe place for us to discuss all these problems and worries," explains Devlin.

Before they launched the club, Devlin and Cassin realised that they needed to get their consultants on board, so that trainees could take an hour's break over lunch.

To do this, Devlin wrote a paper citing the Institute for Healthcare Improvement's work on enhancing wellbeing at work, ${ }^{1}$ research by the Royal College of Anaesthetists on the risk of burnout among trainees, ${ }^{2}$ and findings from a survey he had conducted of his fellow trainees.

The report secured support from the consultants, but the pair faced other challenges. It was difficult to find a private room where trainees could discuss clinical cases and in the end they used the doctors' mess, though this wasn't ideal as it was quite a way from where the trainees worked.

The second challenge, Devlin says, was keeping the club going. While the meetings were well attended when they first started in January, numbers dropped after six weeks when the trainees moved on to new jobs. Devlin says that ideally the club should have begun when the trainees started their new jobs at the hospital and he has plans to relaunch.

"The lunch club concept definitely improves wellbeing," Devlin reflects. "It provides an opportunity for doctors to share experiences, build confidence, and enjoy themselves at work.

"Just having that protected time means that you have got something to look forward to in your working day."

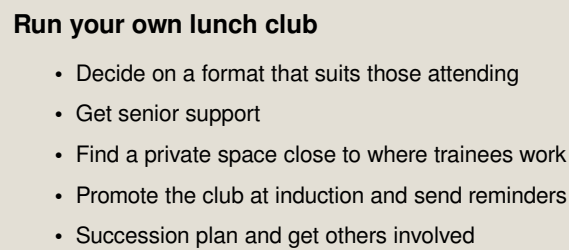

Perlo J, Balik B, Swensen S, Kabcenell A, Landsman J, Feeley D. IHI framework for improving joy in work: IHI white paper. 2017. www.ihi.org/resources/Pages/IHIWhitePapers/ Framework-Improving-Joy-in-Work.aspx.

2 Royal College of Anaesthetists. A report on the welfare, morale, and experiences of anaesthetists in training: the need to listen. 2017. www.rcoa.ac.uk/system/files/WelfareMorale2017.pdf.

Published by the BMJ Publishing Group Limited. For permission to use (where not already granted under a licence) please go to http://group.bmj.com/group/rights-licensing/ permissions 